\title{
Tiny Real Estate Bubbles
}

Jeff Kuss, (E-mail: kuss_1@fortlewis.edu), Fort Lewis College

Rick H. Mull, (E-mail: mull_r@fortlewis.edu), Fort Lewis College

Stephanie Owings, (E-mail: owings_s@fortlewis.edu), Fort Lewis College

\begin{abstract}
This case is appropriate for a course in introductory real estate, real estate analysis, or economics. It provides a basis for developing an understanding of the economics of real estate markets, price to rent ratios, and speculative bubbles. The student plays the role of an external consultant to a fictitious real estate investment firm. This firm is interested in expanding its investment portfolio in small towns with tourist based economies. Real data from the Durango real estate market is provided. There are signs that the market may currently be in or possibly nearing the end of a speculative real estate bubble. Students are asked to evaluate this market and form a conclusion regarding the markets over or under valued condition. This case provides students an opportunity to consider property values based on factors other than a discount cash flow analysis. Depending on the instructor's guidance, students can examine the case from two processes; 1) use of only the real data provided in the case or 2) further research and gathering of additional micro and macro market data. In either case the main objective of the case is for the student to develop a formal analysis and draw a conclusion regarding the current local real estate market's over or under valuation condition.
\end{abstract}

\section{INTRODUCTION}

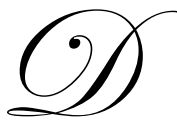

ila Partners is a Portland, Oregon based real estate investment partnership that has been in existence for 10 years. During those 10 years Jan Dila, Joe Williamson, and Tino Garcia have managed to accumulate real estate property with a total asset value of over $\$ 60$ million. Their current equity position in this partnership totals at just over $\$ 6$ million. Their successful strategy for the last 10 years has been to examine various small-town markets across the country with a tourism base and make conservative, low risk investments in properties in those communities. Their objective has been to maximize investment price appreciation with minimal cash flow risk. Jan became interested in Durango, a small-town in southwestern Colorado after visiting Three Springs Ranch-a "new urbanism" project being developed by the Ute Indian Tribe.

The firm has compiled the following information, and is providing it to you as its hired consultant for this project. The partners are requesting you use the provided information to develop a conclusion regarding the Durango real estate market's over or under valued condition. They have asked for both a written report and a formal presentation on your findings.

\section{LOCAL TOURISM ATTRACTIONS}

The town of Durango, population 15,000, is located in southwest Colorado, with a total county (La Plata) population approximately 44,000. It is a geographically isolated region, does not have an interstate, and the nearest major metro area is Albuquerque, New Mexico which is approximately 220 miles from Durango. The next closest metro area is Denver, Colorado which is approximately 340 miles away. Durango has an airport, which serves about 100,000 passengers per year, and is regularly served by only two commercial carriers (United and America West). Neither of these airlines provides jet service to the region.

Durango is supported economically by a large tourist industry, and its primary tourist attractions are the Durango-Silverton Narrow Gauge Railroad, the Durango Mountain Resort Ski Area and Mesa Verde National Park. The railroad serves approximately 100,000 travelers per year for the historic ride between Durango and Silverton. 
Durango Mountain Resort is approximately 25 miles north of Durango, and has 1200 acres of skiable terrain served by 11 lifts. It is one of 25 major ski resorts in the state and is of moderate relative size. Approximately 35 miles west of Durango is Mesa Verde National Park, an archeological site with preserved cliff dwellings. They have approximately 600,000 visitors per year. By comparison, Yellowstone has about 3 million visitors per year, Yosemite has about 3.5million visitors per year and Zion has about 2.6 million visitors per year.

\section{SPECULATIVE REAL ESTATE BUBBLES}

Many of Durango's investors and Realtors believe that the current historically high property prices suggest Durango real estate might be in a "speculative real estate bubble". Others disagree, and point to the prices of properties in other metropolitan and upscale mountain town areas, such as Telluride and Aspen, as evidence of the potential upper end of property prices. This last group believes the town will continue to see property values appreciate in the foreseeable future.

The term "speculative real estate bubble" has several connotations. Robert Shiller, a Yale economist and author of Irrational Exuberance, defines it as "a situation in which temporarily high prices are sustained largely by investors' enthusiasm rather than by consistent estimation of real value." (pg. xviii, $2^{\text {nd }}$ edition). John Krainer, a Federal Reserve Bank economist states that "A bubble occurs - in either the stock market or the housing marketwhen the current price of an asset deviates from its fundamental value." To make either of these definitions meaningful one must understand that the fundamental value of an asset, in an investment sense, is based on the timing, risk, and size of the estimated future cash flows from that asset; in this case in an investment property.

Although many may debate whether speculative bubbles currently exist in any given market, after the fact, a bubble is generally easily recognized. Everyone now seems to be in agreement that, from 1995 to 2000, the stock market experienced a bubble. In the real estate sector, there is general agreement that Japan, and particularly Tokyo, experienced a speculative bubble in the mid-1980s. Japanese property prices peaked in 1991 and then fell for the next 14 consecutive years (The Economist, 6/18/2005).

\section{THE DURANGO REAL ESTATE MARKET}

The town of Durango is nestled in a valley to the east and west, and bounded by a river flood plain to the north, severely limiting the ability of the town to expand its housing stock. The current primary corridor of development is to the southeast of the town. This area is topographically flat and is currently primarily agricultural land, easily lending itself to development.

Some believe that the increase in Durango's population, coupled with the limited availability of land which can be easily built upon, can explain the increase in property prices. However, housing price increases in Durango since 1995 appear to have been disproportionately larger than population increases (see Table 1). Larger percentage increase in housing prices than population might be explained by an increase in housing stock quality. For example, if new homes are built which are of significantly higher quality than the previously existing housing stock, then it would be expected that housing price increases would outpace population increases. However, the order of magnitude between the population change and the change in the real price of a single family home makes this explanation, at best, incomplete. 
Table 1: Durango, Colorado Population Changes, Average Nominal and Real Single Family Prices, and Percent Changes in Prices from 1996 to $2005^{1}$

\begin{tabular}{|c|c|c|c|c|c|}
\hline Year & $\begin{array}{c}\text { Durango } \\
\text { Population }\end{array}$ & $\begin{array}{l}\text { \% change in } \\
\text { population } \\
\text { year to year }\end{array}$ & $\begin{array}{c}\text { Average nominal price } \\
\text { of a single family } \\
\text { home, Durango }\end{array}$ & $\begin{array}{c}\text { Average real price of a } \\
\text { single family home, } \\
\text { Durango }\end{array}$ & $\begin{array}{l}\% \text { change in real } \\
\text { price, year to year }\end{array}$ \\
\hline 1996 & 13,350 & & $\$ 202,611$ & $\$ 252,212.09$ & \\
\hline 1997 & 13,278 & $-0.54 \%$ & $\$ 189,537$ & $\$ 230,632.87$ & $-8.56 \%$ \\
\hline 1998 & 13,468 & $1.43 \%$ & $\$ 200,090$ & $\$ 239,739.74$ & $3.95 \%$ \\
\hline 1999 & 13,731 & $1.95 \%$ & $\$ 208,455$ & $\$ 244,365.32$ & $1.93 \%$ \\
\hline 2000 & 13,922 & $1.39 \%$ & $\$ 239,501$ & $\$ 271,629.18$ & $11.2 \%$ \\
\hline 2001 & 14,708 & $5.64 \%$ & $\$ 245,585$ & $\$ 270,822.98$ & $-0.3 \%$ \\
\hline 2002 & 15,231 & $3.56 \%$ & $\$ 276,538$ & $\$ 300,210.51$ & $10.85 \%$ \\
\hline 2003 & 15,324 & $0.61 \%$ & $\$ 307,119$ & $\$ 325,980.11$ & $8.58 \%$ \\
\hline 2004 & 15,628 & $1.98 \%$ & $\$ 343,288$ & $\$ 354,918.72$ & $8.88 \%$ \\
\hline 2005 & 16,428 & $5.12 \%$ & $\$ 388,792$ & $\$ 388,792.00$ & $9.54 \%$ \\
\hline \multicolumn{2}{|c|}{ Total \% change } & $23 \%$ & & & $54 \%$ \\
\hline
\end{tabular}

\section{HOUSING MARKET'S PRICE-TO-EARNINGS RATIOS}

Recently, economists have begun to calculate the ratio of the average price of a home to the average annual rental rate. This is called the Price to Rent or PR ratio. This is considered to be a statistic that is analogous to a stock's PE ratio.

Stock market analysts often use a firm's price-to-earnings (PE) ratio, today's price divided by the previous year's earnings, as a value indicator. PE Ratios indicate the amount that investors are willing to pay, the market price of the stock, for a dollar of earnings. Higher PE ratios will reduce investor's percentage return, but they are often justified by pointing to anticipated future growth in earnings. The idea is that the firm's earnings will hopefully "grow into" its current price. Relatively high PE ratios were prevalent during the dot.com boom and can be considered warning indicators of a speculative boom.

The logic of a PR Ratio and its similarity to a PE Ratio is straight forward: purchasing a home at a given price, $\mathrm{P}$, as an investment, one can expect it to yield one year's rent, $\mathrm{R}$, as earnings. There are several private and published sources of PR Ratios. One such private firm is managed by Edward Leamer, a professor of economics at UCLA. Other sources include The Federal Reserve Bank of San Francisco which has created a price to rent ratio at the national level for the United States for the years 1982 to $2003^{2}$ as well as The Economist which follows this statistic at the international level.

It is important to understand that there is a slight overestimate bias in the PR Ratio in what would be considered a "normal" housing market. To see this, first recognize that there are two types of homes which come up for sale: owner-occupied homes and rentals. On average, rental homes are smaller and likely subjected to more abuse than owner-occupied homes. As a result, one would expect the average rental home to sell for less than the average owner-occupied home (larger and better maintained.)

\footnotetext{
${ }^{1}$ Note: average price of a single family home is taken from data published by Don Ricedorff, a local real estate agent. Although citing the Durango Area Association of Realtors for this data, they were unable to provide the full time-series and the average sales price and volume data which they did provide did not exactly match this data. The differences, however, can be regarded as incidental.

${ }^{2}$ For house price, Krainer uses the existing home sales price index published by OFHEO. This is a broad measure of the movement of single-family house prices. For rent, Kraimer uses the owner's equivalent rent index published by BLS. This is a time series which attempts to determine price of shelter services provided by owner-occupied housing. That is, it approximates what a homeowner would pay to rent, or would earn from renting his home. The owner's equivalent rent index was calculated in different ways for the time periods 1982-1987, 1987-1997 and 1997-2003.
} 
If $\mu$ is the average price of a owner-occupied home, the average price of a rental will be [ $\mu--\alpha$ where $\alpha$ is some decrease in value associated with size or quality. Thus, during normal, non-speculative times the PR is overestimated for a rental property, since the typical landlord paid less than the average price of a home.

During a time of speculative froth in the real estate market, speculators begin to purchase homes that have been owner-occupied and turn them into rentals, which would be expected to affect both the numerator and the denominator of the PR. The increase in demand for real estate (from both owner-occupied and speculative investment markets) puts upward pressure on the price. The average quality of rentals should increase, putting upward pressure on R (Rent). However, the number of rentals supplied to the market will also increase, putting downward pressure on R. Thus, it is not clear whether R will rise or fall. However, the rate of change in P should overwhelm even an upward movement in $\mathrm{R}$, leading to a rising PR.

Consider what happened to Durango's PR over a 10 year period. The advantage to considering time series data is that the flaw in the statistic remains consistent over time. That is, although the PR for any given year may over-estimate what landlords really paid for a dollar's worth of rent, a rising PR over time should suggest that rental housing is becoming a less attractive investment.

\section{AVERAGE RENTAL RATES IN DURANGO}

The Colorado Division of Housing, in conjunction with Dr. Gordon Von Stroh of the University of Denver, publishes the Multi-Family Vacancy and Rental Survey. Rental rates collected by this survey are for unfurnished units where tenants pay electricity and gas. ${ }^{3}$ The survey contacts owners and property managers of multi-family rental housing. Participation is voluntary and the information collected on individual complexes is not made publicly available.

Table 2 reports the average rental rates reported by this survey. Only rental property within the city limits of Durango is considered. The annual figure is created by averaging the February and September rates. The 2005 September survey considered 583 units. These 583 units consisted of: 31 efficiency units, 122 one bedroom units, 215 two bedroom/1 bath units, 159 two bedroom/2 bath units, 56 three bedroom units.

The third column of Table 2 converts the nominal rental rates into real values. These real values were created using the average CPI for each year. Real rental rates are all expressed in 2005 dollars. Note that real rental rates are actually lower in 2005 than they were in 1996. The average real rental rate over the 10 year period was $\$ 745$.

Table 2: Average Rental Rates in Durango

\begin{tabular}{|c|c|c|c|}
\hline Year & Average Rental Rate & Real Rental Rate & $\begin{array}{c}\text { \% change real rent from } \\
\text { previous year }\end{array}$ \\
\hline 1996 & $\$ 615.14$ & $\$ 765.68$ & $-1.3 \%$ \\
\hline 1997 & $\$ 621.09$ & $\$ 755.76$ & $-16.5 \%$ \\
\hline 1998 & $\$ 526.73$ & $\$ 631.11$ & $15.8 \%$ \\
\hline 2099 & $\$ 623.67$ & $\$ 731.10$ & $1.1 \%$ \\
\hline 2001 & $\$ 652.02$ & $\$ 739.48$ & $9.8 \%$ \\
\hline 2002 & $\$ 736.30$ & $\$ 811.96$ & $-2.9 \%$ \\
\hline 2003 & $\$ 726.04$ & $\$ 788.19$ & $-7.5 \%$ \\
\hline 2004 & $\$ 687.22$ & $\$ 729.42$ & $4.1 \%$ \\
\hline 2005 & $\$ 734.63$ & $\$ 759.52$ & $-2.8 \%$ \\
\hline
\end{tabular}

Source: Colorado Division of Housing Multi-family Vacancy and Rental Survey. Real rental rate calculated using CPI.

\footnotetext{
${ }^{3}$ This is an excellent feature of this data series. Ideally, we would have access to "implicit rent": what a homeowner would pay to rent his home. Because homeowners pay for utilities and furnishings separately, we want to consider the rent on unfurnished units where renters pay for utilities.
} 


\section{THE DURANGO PRICE TO RENT RATIO}

The Economist has tracked the price to rent ratio at the national level for multiple countries. Their methodology compares current (2005) price to rent ratios in a nation to that nation's 25-year average (1975-2000). They found:

house prices have hit record levels in relation to rents in America, Britain, Australia, New Zealand, France, Spain, the Netherlands, Ireland and Belgium. This suggest that homes are even more over-valued than at previous peaks, from which prices typically fell in real terms...America's ratio of prices to rents is $35 \%$ above its average level during 1975-2000. By the same gauge, property is overvalued by 50\% or more in Britain, Australia and Spain. (The Economist, June 18, 2005)

Table 3 depicts Durango's historical PR Ratio. Column two (PR Ratio 1) was constructed using the average price of a single-family home in Durango. This allowed for the longest possible time series. Using the methodology of The Economist, an average price to rent ratio of approximately 25 for the years 1995-2000 is calculated. This means the price to rent ratio in 2005 is more than $70 \%$ above its previous average. By The Economist's standards, the Durango real estate market would be considered to be significantly over-valued. However, The Economist is comparing recent performance to a 25-year average as opposed to the 5-year average available for the Durango market.

Table 3: Average Price to Rental Ratios in Durango

\begin{tabular}{|c|c|c|c|}
\hline Year & PR Ratio 1 & PR Ratio 2 & PR Ratio 3 \\
\hline 1996 & 22 & & \\
\hline 1997 & 21 & & \\
\hline 1998 & 26 & 22 & 16.3 \\
\hline 1999 & 28 & 25 & 17.5 \\
\hline 2000 & 31 & 22 & 15.9 \\
\hline 2001 & 28 & 27 & 18.2 \\
\hline 2002 & 32 & 30 & 20.8 \\
\hline 2003 & 37 & 34 & 28.4 \\
\hline 2004 & 39 & 38 & 31.6 \\
\hline 2005 & 44 & & \\
\hline
\end{tabular}

Table 4: Percent change in the price to rent ratio between 2000 and 2005 for Durango, Colorado

\begin{tabular}{|c|c|}
\hline Place & \% change \\
\hline Price to Rent Ratio 1 & $41.9 \%$ \\
\hline Price to Rent Ratio 2 & $52.0 \%$ \\
\hline Price to Rent Ratio 3 & $80.5 \%$ \\
\hline
\end{tabular}

Table 3, PR Ratio 2 was constructed using a weighted average ${ }^{4}$ price. This weighted average considered the price of single family homes, town homes and condominiums. The PR constructed using this approach applies a more consistent comparison; the rental market consists of a mix of homes, town homes and condominiums. However, data on town home and condominium sales was unavailable before 1999 (data supplied by the Durango Area Association of Realtors). Column 3 shows a 52.0\% increase in the price to rent ratio between 2000 and 2005 in Durango. Using the data for PR Ratio 1, there was a 41.9\% (Table 4) increase in the price to rent ratio between 2000 and 2005.

\footnotetext{
${ }^{4}[(\#$ of homes sold $)($ avg. price of a home $)+(\#$ of condos -townhomes sold $)($ avg. price of a condo $\sim$ townhome $)]$
} 
Table 3, PR Ratio 3 was constructed using only the average price of town homes and condominiums. A home often comes with certain features (for example, a yard) that multi-family units don't have. As a result, comparing average home price to the average rental rate of apartments will bias the PR upward. Calculating the PR using only condo and townhouse prices generates a more believable number. That is, the pure PR of 31.6 is within the upper range of the PR in other major metro areas. The other PR's which we have calculated were out of this range. However, calculating the PR using only condo and town home prices yields an $81 \%$ increase in the price to rent ratio between 2000 and 2005.

The New York Times contracted with Economy.com to calculate the price to rent ratio in major metro areas. Table 5 shows the percent change in the price to rent ratio between 2000 and 2005 in ten metro regions considered to be at risk of a speculative bubble. The average percent change in the price to rent ratio in these ten regions was $130 \%$. Table 6 shows the percent change in the price to rent ratio between 2000 and 2005 in ten metro regions where home price growth has been much more stable. The average percent change in the price to rent ratio between 2000 and 2005 in these ten regions was $17.6 \%$.

Table 5: Percent change in the price to rent ratio between 2000 and 2005 in areas considered to be as speculative risk. Based on data collected by Economy.com and reproduced in the NY Times, May 28, 2005

\begin{tabular}{|c|c|}
\hline Place & \% change \\
\hline San Francisco, CA & $173 \%$ \\
\hline San Jose, CA & $141 \%$ \\
\hline W. Palm Beach-Boca Raton, FL & $153 \%$ \\
\hline San Diego, CA & $114 \%$ \\
\hline Sacramento, CA & $130 \%$ \\
\hline Orange County, CA & $118 \%$ \\
\hline New York City metro area & $140 \%$ \\
\hline Los Angeles-Long Beach, CA & $102 \%$ \\
\hline Fort Lauderdale, FL & $111 \%$ \\
\hline Miami, FL & $113 \%$ \\
\hline
\end{tabular}

Table 6: Percent change in the price to rent ratio between 2000 and 2005 in areas considered to be stable. Based on data collected by Economy.com and reproduced in the NY Times, May 28, 2005

\begin{tabular}{|c|c|}
\hline Place & \% change \\
\hline Tulsa, OK & $24.7 \%$ \\
\hline Oklahoma City, OK & $25 \%$ \\
\hline Pittsburgh, PA & $28.6 \%$ \\
\hline Columbus, OH & $15.7 \%$ \\
\hline Birmingham, AL & $17 \%$ \\
\hline Salt Lake City, UT & $18.3 \%$ \\
\hline Indianapolis, IN & $10.3 \%$ \\
\hline Greenville-Spartanburg-Anderson, SC & $12.3 \%$ \\
\hline Albuquerque, NM & $3.5 \%$ \\
\hline
\end{tabular}

Using PR metrics suggests that Durango is not at either extreme. Durango may not be as likely to suffer a prolonged real estate price contraction as are California and Florida. However, growth trajectory has not been as secure as it has been in many of the mid-western areas.

\section{CONTAGIONS: IN-MIGRATION TO DURANGO}

Even if Durango itself has not experienced a speculative run-up in real estate prices, there is concern among the partners that it could import the positive or negative effects of other real estate markets providing either net in or out-migration to Durango. 
To begin to address this concern, data was obtained from an extensive data base of real estate transactions in the Durango region ${ }^{5}$ and illustrated in Table 7 below. It was developed by reviewing the transfer deed for all residential real estate transactions in La Plata County. Out of 1328 transfer deeds, 514 of the purchasers of real estate were already living in La Plata County. That is, about 39\% of the homes sold in La Plata County went to individuals who were previously renting a unit in La Plata or who had sold one home here and bought another (an in-area re-location). About 8\% (105) of the homes sold in La Plata County were purchased by individuals who had previously resided in neighboring counties (San Juan, NM; Archuleta, CO; Montezuma, CO; Montrose, CO). Just over half of the homes in La Plata County are purchased by individuals who previously lived outside of the four corners region.

Table 7: La Plata Country In-Migration Characteristics for Property Purchasers based on Transfer Deeds and U.S. Internal Revenue Service Data. Data collected Bob Allen, Durango, Colorado

\begin{tabular}{|c|c|c|c|}
\hline Purchaser Previous Location & Number & & Percen \\
\hline La Plata County (current resident) & 514 & & $39 \%$ \\
\hline Neighboring Counties* & 105 & & $8 \%$ \\
\hline \multicolumn{4}{|l|}{ Outside Four Corners Region } \\
\hline Front Range counties: Denver, Boulder, Jefferson, Larimer, El Paso and Arapahoe & & $8 \%$ & \\
\hline Colorado: Other & & $25 \%$ & \\
\hline Maricopa County (Phoenix) Arizona & & $2 \%$ & \\
\hline Arizona: Other & & $3 \%$ & \\
\hline Texas & & $3 \%$ & \\
\hline California & & $5 \%$ & \\
\hline Florida & & $2 \%$ & \\
\hline California & & $5 \%$ & \\
\hline Total: Outside Four Corners Region & 709 & & $53 \%$ \\
\hline Total Transfer Deeds & 1328 & & $100 \%$ \\
\hline
\end{tabular}

* San Juan, NM; Archuleta, CO; Montezuma, CO; Montrose, CO

U.S. Internal Revenue Service data provides additional insight into where Durango in-migrants are relocating from. About 7.5\% of La Plata County homes are purchased by people who had previously resided in six Front Range counties: Denver, Boulder, Jefferson, Larimer, El Paso and Arapahoe. About 2\% of Durango homes are purchased by people who had previously resided in Maricopa County, Arizona (which is home to Phoenix). Using transfer deed data, Allen calculates that about $2 \%$ of all of the La Plata County homes sold go to former Floridians, 3\% go to former Texans, $4 \%$ go to former Arizonians, and 5\% go to former Californians. About 33\% of La Plata County homes are sold to Coloradoans who previously lived outside of La Plata, Archuleta, Montezuma and Montrose Counties.

\section{CONTAGION: SECOND HOMES}

The Region 9 Economic Development District of Southwest Colorado commissioned a study on second homes in Southwest Colorado. They defined second homeowners as property owners whose mailing addresses are outside of the county in which they own property. Thus, second homeowners would, generally, be categorized as inmigrants in a transfer deed data set since their address on the transfer deed would be outside of the county. ${ }^{6}$ However, they are not, in fact, in-migrants; their primary residence is outside of La Plata County.

\footnotetext{
${ }^{5}$ This data was supplied by Bob Allen, a private real estate consultant who conducts appraisals and performs market analysis.

${ }^{6}$ The exception to this generality would be someone who purchased a property in La Plata County, moved outside of the county, but did not sell the property. On a transfer this person would appear to be a local, living in La Plata County, even though they now actually own a second home in La Plata County.
} 
The data collected and presented in Table 7 above is flow data, indicating that in any given year about half of the homes in La Plata County are purchased by individuals who previously lived outside of the four corners region. This is important in determining who is driving annual demand for home purchases.

The data collected by The Region 9 Economic Development regarding second homes is stock data. It is the result of many years of accumulated flows. It tells us how much of our current housing stock is owned by non-local residents. Specifically, $17 \%$ of single family dwellings and $55 \%$ of condominiums in La Plata County are owned by non-locals.

The Region 9 Economic Development study reveals the location of second home owners' mailing addresses. This is reproduced in Table 8. They aggregate all types of properties: residential, vacant lands and agricultural lands. Nonetheless, it provides a notion of the origin of external demand for real estate in La Plata County.

Table 8: Mailing Address, by State, of Non-Locals who own property in La Plata County as a \% of all non-locals who own property in La Plata County

\begin{tabular}{|c|c|}
\hline State & $\%$ \\
\hline Arizona & $16 \%$ \\
\hline California & $15 \%$ \\
\hline New Mexico & $15 \%$ \\
\hline Texas & $14 \%$ \\
\hline Colorado & $13 \%$ \\
\hline Florida & $4 \%$ \\
\hline
\end{tabular}

Comparing the flow data from Table 7 stock data of Table 8, it is clear that out-of-state demand, be it for second homes or in-migration, comes primarily from Arizona, California, Colorado, New Mexico and Texas.

\section{EXTERNAL REAL ESTATE MARKETS IMPACTING DURANGO}

Recall that about 50\% of Durango real estate is sold to individuals who previously lived outside of the four corners region., thus it is important to know the health of the real estate markets from which out-of-area purchases come.

According to The Wall Street Journal (7/20/2006, D1), the real estate market in Texas is healthy. In Houston, housing inventory is shrinking, home prices are heading up and job growth is very strong. In Dallas, housing inventory is up slightly, home prices are heading up and job growth is very strong. In Denver, the real estate market is softening, with inventories rising by $24 \%$ over the last year and home prices heading down. However, the job outlook in Denver is characterized as strong. In California, housing inventories have risen much more precipitously. Relative to last year, inventories in Los Angeles are up 175\%, in San Francisco they are up 112\% and in San Diego they are up 92\%. Job creation in San Francisco and San Diego are both regarded as average whereas job creation in Los Angeles is projected to fall below the national norm. In Phoenix, the year over year change in housing inventory is a remarkable $298 \%$ and housing prices are falling. However, their job outlook is characterized as very strong. In Miami, housing inventory is up $245 \%$ and the employment outlook is characterized as weak. However, population growth is expected to absorb the accumulated housing inventory over the next year to 18 months. In Tampa housing inventory has grown by $294 \%$ over the last year and in Orlando housing inventory has grown by an astounding 397\% over the last year. Both markets are experiencing declining prices but their employment outlook is strong.

None of these feeder markets appear to be imploding. However, the California, Florida and Arizona markets are clearly weakening. The Durango real estate market is vulnerable to declines in these markets. 


\section{FINAL NOTES}

Dila Partners is specifically considering investment in the "Three Springs" sub-division currently under construction at the southeastern edge of the town. It is estimated that 150 homes per year will be built in this subdivision over the next 10 years. In contrast, there were 219 in-town homes sold, 267 condos/town homes sold and 357 country homes sold in the Durango area during 2005. Using this broad measure total (843), the Three Springs development will result in an annual increase in available homes of about $18 \%$. This is a conservative estimate.

While the firm has compiled substantial information, it is providing it to you as its hired consultant for this project. Your past record with the firm has led them to believe that your assessment of the market and its over or under valued condition is critical to their decision process. They have asked for both a written report and a formal presentation on your conclusions.

\section{Teaching Notes}

Study replication:

1. The hardest part of replicating this study for another housing region is locating the average rental rates. Note that the information for this case study came from the Colorado Division of Housing. The state is interested in the availability of affording housing and average rental rates are part of making this determination. Try searching at your state's equivalent to the Colorado Division of Housing to find average rental rates.

Average housing prices can typically be found from your local Realtor Association. Many real estate firms also keep track of this data. As is mentioned in the case study, it is preferred to gain access to a data set that includes condos and town homes in addition to single-family dwellings.

In-migration statistics can be found from IRS tax payer migration data. This is probably only necessary if the market you are studying is also resort region.

2. Begin by asking your students to discuss the important details of the discounted cash flow analysis when considering real estate investments. Since this case is basically an assessment of the risk of investing in the Durango market, ask them to explain how this type of risk might be incorporated into a discounted cash flow analysis.

a. One way that risk might be incorporated into a discounted cash flow analysis is through the use of a scenario analysis. In a scenario analysis one might consider a high, medium and low rental rate for the properties. In this case three scenarios would be developed. Additionally, one could consider a high, medium and low future value of the property based on the speculative nature of the market. In this way, the risk is incorporated into the actual cash flows of the project.

b. A second way risk might be incorporated is through variants of the discount rate. The firm should consider its average discount rate for projects that are of average risk. If this project was considered riskier than the other real estate investments in the firm's portfolio, then the discount rate could be increased to compensate for this risk.

3. Ask the students to relate how a study of the market, as this case does, is directly related to a discounted cash flow analysis.

a. This case sets up a basis for risk adjustment in the discounted cash flow analysis approach. By studying the market in a different geographical region, a more accurate assessment of the risk of investing in the geographical area is determined. Since this is potentially a speculative real estate market, and the firm is concerned that we are at the end of this cycle, there is considerable reason to carefully evaluate the market and determine whether the rest should be adjusted. 
b. The specific risk adjustments that could be incorporated into the discounted cash flow analysis after the market study and conclusions are complete, is outlined in question two above.

4. Discuss with your students possible flaws in the data and how these flaws might bias the results. For instance:

a. Average rental rates reflect the rents of multi-family housing units. If a significant percent of the rental stock consists of homes, privately owned condos or town homes, or rooms in homes then this data might not reflect the true average amount paid by renters. Whether the reported average is biased up or down will depend on the quality of the multi-family units relative to individually owned rental units. Of course, rents aren't set in a vacuum. As rental rates for multi-family housing units change this will affect what owners of individual rental units can charge.

b. The P in the calculated PR is the price of a home. Homes can be rented. However, the R in the PR is not the average rent paid on a single-family home. The $\mathrm{R}$ is the average rent paid on a rental unit in a multi-family complex (an "apartment building"). It initially appears that in calculating the PR we are comparing apples to oranges. However, the rent which can be charged on a X-bedroom house influences the rent which can be charged on a X-bedroom unit in an apartment complex. These rents are not identical values but they tend to be closely related. If rents on two-bedroom apartments rise there is every reason to think rents on 2-bedroom homes will also.

5. Ask your students to explain why the comparison of PR ratios across regions is done on a percent basis.

a. The value of a time series data is that flaws in the data are held constant. Thus, in a particular region, changes in the PR over time are informative even if the PR itself is not a "perfect" statistic.

b. However, to compare across regions at any particular point in time, the PR ratio must have been calculated in the same way for both regions. Thus, we do not compare the PR in San Francisco with the PR in Durango. In fact, the published PR in San Francisco in 2005 was 34.1. Since the calculated Durango PR was higher (unless you use the condo-townhome only data), it is highly likely that Economy.com used an alternative (and probably superior) data set. They may have had access to the average price of a rental home which they could compare with the average price of a home. They may have been able to adjust this figure, as the Department of Labor does, into a rental equivalence statistic. Nonetheless, comparing the percent change in a consistently flawed statistic with theirs is a meaningful calculation.

6. Ask your students to discuss how speculative bubbles in other markets might affect the demand for real estate in the Durango market.

a. If a substantial percent of housing demand comes from individuals who are located in booming markets, these potential in-migrants might be more likely to liquidate their present real estate holdings in order to re-locate to Durango thus increasing demand for Durango homes.

b. If a substantial percent of housing demand comes from individuals who are presently living in regions where housing prices are already declining and housing inventory is building, they may be unwilling to liquidate their current holdings and there-by lock-in their loss.

7. Discuss the difference between flow data and stock data.

a. $\quad$ Flow data (the Bob Allen data) tends to be superior because it is more recent and tends to give a better picture of the origin of demand on a regional basis.

8. Discuss with your students when it is appropriate to use real data and when it is appropriate to use nominal data.

a. For instance, in Table 1 the real price change must be compared with the change in population. Using the nominal change in housing prices would exaggerate the difference because it includes the effects of inflation. In nominal terms, rental rates went up between 1996 and 2005. However, when the effect of inflation is netted out, an average landlord is earning less from his rental property in 2005 than he did in 1996 ! 
9. Ask your students to consider why PR ratios don't need to be calculated in real terms.

a. $\quad$ PR ratios do not need to be calculated in real terms sine they are a pure number (the $\$ s$ in the numerator and denominator "cancel out"). Thus, they can be compared over time without bias.

10. Ask your students to consider the fact that the firm uses an average discount rate of $20 \%$ for its average risk projects. Tell them that the next step in the process, but not to be completed for this case, is to conduct a discounted cash flow analysis of the project. Recall that the firm's investment strategy is to make a series of conservative investments in properties. Based on their conclusion regarding the speculative nature of this market, ask them to comment on how they might proceed with a discount rate risk adjustment in their discounted cash flow analysis.

a. It is unlikely that anyone will make an effective argument that the Durango market is less risky than the firm's current investment portfolio, even though that information has not been provided. The fact that the firm makes conservative investments and, at the very least, this market appears to have some risk, the argument for decreasing the discount rate cannot be made.

b. Some students may argue that the rest of the Durango market might be of the average risk with other investments in the firm's portfolio. Although this is unlikely, in the event that this argument is made and concluded by the class that discounting of the estimated cash flows should be at the firm's average $20 \%$.

c. It is likely that the class will conclude that the speculative nature of the market indicates that in the investments in this market will be of higher risk than the firm's average risk investments. If this is the case, then there can be considerable discussion about the specific increase in the discount rate. There is no correct answer here, but this provides a basis for a lively class discussion.

d. One possible way to illustrate the impact of increasing the discount rate on the project's value is to set up a brief spreadsheet with some sample cash flows, and estimated future value of the property. Various discount rates for this project's cash flows can be used to illustrate the impact and range of values obtained when increasing the discount rate. This will give the students a general feel for a reasonable range of discount rates to consider. 
NOTES 